\title{
Conceptualizing environmental governance on the GBM basin
}

\author{
Marufa Akter ${ }^{*}$
}

\author{
${ }^{*}$ Correspondence: \\ makter@bigsss.uni-bremen. \\ de; maktermimi@gmail.com \\ Bremen International \\ Graduate School of Social \\ Sciences, University \\ of Bremen, UNICOM, \\ Mary-Somerville-Strasse 7 \\ (Haus Wien), Room: 7.4590, \\ 28359 Bremen, Germany
}

\begin{abstract}
River water sharing is an issue that is dealt by the South Asian neighboring countries for the last four decades. Water management of Ganges-Brahmaputra Meghna (GBM) basin is a controversial issue, which is not yet developed as a regional cooperative mechanism. The GBM river basin countries also represent the projection of relative power differences among its upper stream and lower stream countries. Considering the geopolitical context and hydro-politics of the region, the study examines potential scopes for effective regional governance to GBM's ecological integrity and to share common river water among China, Bhutan, Nepal, India and Bangladesh. The study uses Rittberger et al. (2006) explanatory model (that explains three conditions-Problem, Cognitive and Hegemonic conditions) in the development of multilateral organizations in GBM region. The study deals with the question-what conditions facilitate GBM based water governance among five main riparian countries (upstream and downstream) in resolving the water scarcity challenges in the region. The paper argues that realization of shortage of water and environmental degradation as an interdependent problem, influence of an inclusive epistemic community (cognitive condition) and a hegemonic leadership (power is willing to accept the relative gain of others states for the absolute gain of itself) — are required to foster water resource governance of the GBM for sustainable development of the region.
\end{abstract}

Keywords: Ganges-Brahmaputra Meghna (GBM) basin, Hydro-politics, Ecological integrity, Water governance, Cognitive community, Hegemonic condition, South Asia

\section{Introduction to the problem complexity}

The natural water mostly used in the South Asian region comes from the Ganges- Brahmaputra-Meghna $(\mathrm{GBM})^{1}$ river basin. The four South Asian countries Bangladesh, Nepal, India and Bhutan are sharing the largest river basin of the world together. China is also part of this GBM delta, nevertheless, it only shares the Brahmaputra along with Bhutan, India and Bangladesh (see Table 1 and Fig. 1). These three major rivers play a significant role in shaping the social and cultural lives of the people of this region. Many rivers in this region are originated in one country and end in another because of the artificial demarcation that took place during the period of decolonization in the mid-twentieth century.

Water is one of the most important natural resources for the people living of the basin countries. About 80 per cent of the water in the Ganges flows in the monsoon months

\footnotetext{
${ }^{1}$ The Ganges-Brahmaputra-Meghna basin comprises of a river system that spans over 1.758 million square km (Dinar
} et al. 2007).

(c) 2016 Akter. This article is distributed under the terms of the Creative Commons Attribution 4.0 International License (http:// creativecommons.org/licenses/by/4.0/), which permits unrestricted use, distribution, and reproduction in any medium, provided you give appropriate credit to the original author(s) and the source, provide a link to the Creative Commons license, and indicate if changes were made. 
(June-September) and very little during the dry season (October-May) (Mirza and Ahmed 2005). However, the region is facing shortage of fresh water as a result of high population growth, increased economic development and atmospheric hostility. The situation poses threats both to water as an environmental resource and a means of survival for about 451 million people dependent on the basin, directly or indirectly (Mirza and Ahmed 2005). As the demand of water increases, the countries sharing the basin are more concerned of fulfilling the internal demand, which leads countries to divert water unilaterally from the river basin without following the existing bilateral agreements between the countries.

The GBM river basin governance is still underdeveloped in South Asia. The region significantly bears some potential threats of internal and inter-state conflicts that can destabilize the coherence of the region. Considering the political context of the region, the paper argues that the water scarcity and ecological integrity in the basin can only be better resolved by a multilateral cooperation framework among the GBM river basin countries. Based on this argument, the study deals with the question-what conditions can facilitate GBM based water governance among four main riparian countries (upstream and downstream) in resolving the water scarcity challenges in the region? Therefore, the study intends to find out the condition for a potential phenomenon (i.e. environmental cooperation within GBM) and explores the strategy that can help in establishing a regional cooperation framework.

The study adopts Rittberger et al. (2006) 'condition triangle' explanatory model in developing a multilateral organizational framework in a regional context to answer the research question. The explanatory model shows how an institutional body can emerge as a product of interactions of the three conditions (problem, cognitive and hegemonic), as a consequence, and not necessarily due to a deliberate phenomenon. The study applies process tracing ${ }^{2}$ approach to explore the possibilities of a multilateral environmental cooperation under the regional context. The approach has comprehensively examined different narratives as a form of a chronicle that purports to throw light on how an event comes about (George and Bennett 2004). It deals with issues of interaction among the government, multilateral and non-government bodies, investigates the causal relations between the different units of analysis (states and civil society actors in GBM basin) and establishes the relationship between dependent and independent variables of the study. The dependent variables of the study are components related to the study objectives, issues like the possibility of a regional organization, the role of regional geo-political reality and the role of transnational environmental problem as an issue of regional cooperation. Besides, the independent variables of the study are the factors (three conditions) that have direct impacts on the dependent variables and help to establish causal connection with the dependent variables. The similarity that enforces the study to adopt this method is that both the study and process tracing method seek to construct a phenomenon (regional cooperation on GBM) by testing an empirical model and by analyzing the historical chronicle of different explanations. The research primarily relies on primary

\footnotetext{
2 According to George and Bennett (2004, 177), "Process tracing method is an indispensable tool for theory testing and theory development not only because it generates numerous observations with a case, but because these observations must be linked in particular ways to constitute an explanation of the case".
} 
and secondary sources of information that include-academic journals, books, public statements, news reports, news articles, treaties related to environmental cooperation or environmental regionalism or regional cooperation.

While Rittberger, Zangle and Staisch's use their analysis in order to explain the development of international organizations, they also indentifies some organizations like EU, African Union as products of the three conditions, those are regional in nature. However, this study modestly engineers the three conditions as a deliberate policy tool to stimulate the contextual specificity of the GBM basin. The analysis in this article highlights how an integrated multilateral water governance mechanism in the GBM region generates the demand for enhanced information sharing, technical supports from the international donors, and convergence of the governments and civil society groups in the programmatic ventures. The empowerment of an inclusive cognitive community-a diverse body of think-tanks, NGOs, media, and the government and non-government experts-with financial and technical supports from the respective governments and international donors is a key contribution of this analysis. They are also well positioned to work with local communities of the basin. Further, a strong and inclusive cognitive community, despite its discontents, could exploit the hegemonic potentials of India and China in enhancing a multilateral cooperation among all the riparian countries in the basin area.

To continue further analysis, the first part of study unfolds the discussion of power politics and its impact on the environmental cooperation in a regional context. The second part of the study elaborates on ("Multilateral governance policies and frameworks on joint river water sharing: South Asia and beyond") the current state of regional cooperation in river water sharing and other broader areas of environmental issues in South Asia. Further, it demonstrates some ongoing state-led and civil society initiated approaches among the concerned countries of the region. In the third part, this study unpacks ("Regional cooperation on river water governance and a potential framework for GBM basin") Rittberger et al.s (2006) model and elaborates the analytical framework with the primary information on critical issues of transboundary river water in South Asia. Finally, the study concludes with the significance of a potential coherent multilateral approach in the region for a better management of the GBM water basin.

\section{Hydro-political dynamics and geo-political importance of GBM river basin}

The geographical setting of south Asian countries is one of the major sources of the contentious relations among them on water issue. According to the Basin at Risk (BAR) ${ }^{3}$ scale values and friendship-hostility index by country region, the Ganges basin is more popularly known because of its 50 years long history of disputes and negotiation. In addition to the complex geographical settings of countries, a long history of antagonistic relations and power imbalances between the countries have resulted in further conflicts between the riparian countries (Yoffe et al. 2003).

Being an upper riparian country, the water endowment in Nepal and Bhutan largely represent a source of hydroelectric power, both for consumption and for earning revenues through export of energy (Iyer 1999). The water resources in India, embodying

${ }^{3}$ BAR Water Event Database compiled all reported instances of conflict or cooperation over international freshwater resources in the world from 1948 to 1999. 
hydroelectric power, navigation and irrigation, have however been exposed to the dangers of floods. On the other hand, the network of rivers represents a source of devastating floods for Bangladesh, serves for irrigation, sustains fisheries and plays a role of controlling water salinity. People living in this basin have been making good use of fertile soil for the cultivation of various types of crops and for fishing.

There are different socio-economic and political realities of the four riparian countries. Being an upper riparian country, Nepal contributes 5 per cent of the long term average annual flow of the Ganges and 70 per cent of the flow during the dry season (Upreti 2006). Nepal is a landlocked country between China and India. Therefore, it is heavily dependent on India for trade and transit to get sea access through India. The population of the country highly depends on agriculture and natural resources. For India, the Ganges is known as 'Mother Ganga' and about 47 per cent of its population lives in the Ganges basin (Shahjahan and Harvey 2012). India is currently the third largest energy consumer in the world and water is vital for its economic growth. Bangladesh is at the downstream end of the basin and more than 80 per cent of the country lies within the basin (Gupta 2008; Shahjahan and Harvey 2012). Bangladesh's agriculture largely depends on the water supply from the basin. It is also expected to rely heavily on its water resources to meet food demands and energy needs of a rapidly expanding population.

Most of the water generated in the GBM basins drain into the Bay of Bengal through Bangladesh. Over $75 \%$ of the total volume of water annually drained by Bangladesh enters the country from upstream India. Bangladesh and India share nearly fifty-four rivers including the Ganges and Brahmaputra and disputes over water sharing of those rivers has been continuing for more than half a century. The origin of the disputes lied in the history when India constructed the Farakka barrage in 1961 on the Ganges. Despite the protest of the then East Pakistan (now Bangladesh), Farakka was designed to divert water from the Ganges southward to the Hughly River primarily to navigate the Calcutta Port. The downstream effects of the barrage obstruct the agro-ecological and well-being of southern Bangladesh (Ahmed and Roy 2007; Condon et al. 2009). Moreover, India claimed diversion is necessary for India's national interest to meet its water demand and blamed Bangladesh of being unreasonable (Ahmed and Roy 2007). The negotiation process of sharing water has been continued until the signing of the Ganges treaty in 1996 (Wolf and Newton 2007). Even today, the Farakka barrage looms large in the minds of many Bangladeshis, fairly or not, as the single most conspicuous symbol of their bigger neighbors 'bullying' tactics and indifference to lower-riparian water needs (Wirsing 2007).

Teesta, ${ }^{4}$ the decade long contention of India and Bangladesh, is absent from any agreements settling the matter of water entitlement. It flows from the southern part of the Himalayan headwater, first through Indian lands and then crossed the border to Bangladesh until it joins the Brahmaputra River. Both Bangladesh and India have constructed the Teesta barrage. ${ }^{5}$ Tipaimukh dam is another disputer persists between the two countries. Massive protest against both the dam and river linking project took place in Bangladesh and India due to the expected consequence over ecological future of the region.

\footnotetext{
${ }^{4}$ A cross-boundary river between India and Bangladesh.

5 Teesta barrage is situated $20 \mathrm{~km}$ south of the Indian border.
} 
Nepal is the upper riparian country for four major rivers (Mahakhali, Karnali, Gandak and Kosi) and regulation of these rivers has been an important issue for both India and Nepal. There are significant disagreements between the India and Nepal on what would be the equal sharing principles implied on the joint boundary rivers (Iyer 1990). Mohakhali is a boundary river, Nepalese drew the inference that it should belong equally to these two countries, and therefore, half of the water belongs to Nepal. The Indian view is that there is no warranty for drawing this kind of inference; that the river can be used by the two countries but does not belong to either (Iyer 1999). Apart from the ownership of the river water, the border obstructions and embankments along the border have affected relations across border communities in Nepal (Swain, 2002). Indo-Nepal relations were also affected by large scale migration of people to Indian territories due to large scale floods in Nepal.

Indian river-linking project ${ }^{6}$ emerges as a potential threat to the whole region. The implementation of the project will have a negative impact on the scarce dry seasonal flow of the Ganges, which will have serious ecological threat to downstream country, Bangladesh (Ahmed and Ahmed 2004). Bangladesh needs water from the basin in the dry season to protect world's largest mangrove wetland ecosystem in the Sundarbans. The river linking project has also been very expensive for Nepal, as it has to bear 50 per cent of the expenses for construction of storage dams within its territory (Ahmed and Ahmed 2004).

Moreover, China has consistently been showing its interest in the Brahmaputra to meet its increasing demands for fresh water and hydropower. The Brahmaputra has huge potential for hydropower generation for both China and India. China has more than 22,000 hydroelectric dams that supplies hydroelectricity to its giant production and consumption sectors and is considered as the world's most aggressive dam builder (Nowshin 2015). China has aimed to divert water from its surplus southern region to the water-scarce regions in the north. The Brahmaputra is on high stake so far as this water diversion process is concerned and any such attempts of diversion of the Brahmaputra waters will likely produce undue consequences for the lower riparian countries-India and Bangladesh. According to the report, China will divert 200 billion cubic meters of Brahmaputra water as a continuation of third phase of its grand SNWDP project (Shahjahan and Harvey 2012). Iyer reflects the Indian perspective by saying that China's control of the water supply downstream could affect aquatic life and displace populations living in the region (Nowshin 2015). Therefore, the diversion will provide China a firm control of the water flow of the Brahmaputra and leave India and Bangladesh in a scarce situation. All these issues are not merely bilateral and have strong probabilities to generate protracted regional disputes and controversies over the shared water resources.

\section{Multilateral governance policies and frameworks on joint river water sharing: South Asia and beyond}

The existing resource sharing arrangements are majorly bilateral in nature and are mostly governed by the geo-strategic thinking of individual countries (Swain 2002). The

\footnotetext{
6 The project aims to connect Barahmaputa and Teesta and transfer large scale of water from the Brahmaputra and Ganges basin to eastern and southern rivers in India (Condon et al. 2009). The project targeted to transfer 1,74,271 million cubic meters mostly from Brahmaputra through the Ganges (Ahmed and Ahmed 2004).
} 
bilateral agreements are broadly constructed by only volumetric measures of water that each country can claim in different seasons (Rahaman 2009; Sneddon and Fox 2006). Besides, countries have generated less emphasis in exploring a workable solution within the basin which could incorporate a group of stakeholders within as well as outside of the states. Nonetheless, multilateral governance framework is significantly absent to manage the use of trans-boundary rivers and the basin ecosystem in South Asia. The big powers-India and China-have avoided international conventions. For example, both these countries have declined to be the signatories of the 1997 UN Convention on the Law of the Non-Navigational Uses of International Watercourses (UNCIW). Only Bangladesh and Nepal are parties to this framework (Chintan 2011). The state of informational sharing among the regional neighbors in regard to the trans-boundary rivers is equally frustrating in South Asia. The existing bilateral agreements provide a framework for cooperation, however, this is often structurally limited due to the state-centric nature of the cooperation and limited scope of the treaties to a particular river. An Asia Foundation Report (2015) summarizes that Bangladesh, India and Nepal have national policies and laws that encourage the disclosure of information regarding the shared rivers, however, the absence of a multilateral framework impedes any proactive disclosures of water-related data and policies for further cooperation. On regional environmental cooperation, South Asian countries have minutely addressed the issues in the regional platform. SAARC devised a policy of regional cooperation in the energy sector. In 2014, the leaders of the SAARC signed a Framework Agreement on Energy Cooperation that aims to promote regional trade and cooperation in water, hydropower and disaster mitigation. In addition to this, the forum has also forwarded a few other regional frameworks in this area.

In July 2008, the SAARC ministerial meeting on climate change at Dhaka asked for close regional cooperation in capacity building and also to raise awareness of climate change (Swain 2011). The SAARC Action Plan on Climate Change (2009-2011) identifies seven thematic areas of cooperation related to: adaptation; mitigation; technology transfer; finance and investment; education and awareness; management of impacts and risks; and capacity building for international negotiations. ${ }^{7}$ Further, SAARC has taken a common position on climate change-related matters at the Conference of Parties (COP) 15 Conference on Climate Change in Copenhagen on December 2009. However, a little has been achieved in establishing any concrete multilateral arrangements apart from meeting regularly and showing the desire of regional environmental cooperation. One of the major constraints of the SAARC, as one scholar has argued, is the state-centric nature of the organization (Rasul 2015). The exclusionary nature of the existing framework of SAARC provokes a biased and unfruitful multilateral cooperation in any critical issues like the trans-boundary river water sharing. Without incorporating multilateral actors and representation of the people living in the basin as an active geopolitical agent, regional transboundary cooperation is hard to sustain in future (Sneddon and Fox 2006).

In addition to the SAARC-led initiatives, there are some significant demonstrations of cooperation at the state and the civil society levels. At the state level, the governments of Bangladesh, Nepal and India initiated preliminary discussions on a potential 
cooperation on hydropower sector. The 15 April 2013 issue of the Hindu reports that the Government of India (GoI) extends its cooperation towards Bangladesh and Nepal in the joint development of the Ganges basin (Mehdudia 2013). This sub-regional framework, as observed by the GoI, has tremendous potentials for hydro-power, navigation, and environmental sectors and in the economy of the co-basin countries. Such transformation in India's role could arguably be considered as an outcome of to counter China's recent unilateral attempts to control the water resources of the Brahmaputra. Scholars have also observed that India expresses its intention to promote a multi-state cooperation on the management of the Brahmaputra River and generate hydropower resources (Dhungel 2013). The initiative would consider Bhutan, India and Bangladesh in the Brahmaputra basin to devise a regional cooperative framework. Dhaka has shown interests to such regional initiatives, nonetheless, Nepal has been cautiously optimistic due to its vulnerable internal political situation (Dhungel 2013).

International donors have facilitated some vital collaboration on joint river water sharing issues. The Observer Research Foundation, Delhi and the Asia Foundation had started an initiative beyond South Asia, known as-Mekong-Ganga Dialogue (MGD), since 2012. The major aim is to create a knowledge-based network and broader support to the multilateral governance in Mekong-Ganga basin. This track II dialogue has promoted dialogues and exchange of information among the activists, experts and government officials from both the regions to devise plan of cooperation on issues of river water sharing, environmental conservation and food-water-energy issues (ORF 2014). The MGD also advocates the need of up-to-date data collected by the state on joint rivers, and exchange of the data at the government-to-government and non-governmentgovernment levels. The shared knowledge would enhance in establishing norms and protocols for a sustainable multilateral governance in the GBM basin.

In both the previous sections ("Multilateral governance policies and frameworks on joint river water sharing: South Asia and beyond" and "Regional cooperation on river water governance and a potential framework for GBM basin"), it is apparent that the regional geopolitics in South Asia and the interest factors of the two diametrically opposing hegemonies of China and India are the most critical issues that obstruct a multilateral framework in GBM water basin. Nonetheless, the basin-based cooperation in GBM has never really exploited the opportunities that could be generated due to a cooperation that goes beyond the inter-state levels. The minimal evidence of the environmental cooperation under the auspices of SAARC is an important example of such failure.

Regional cooperation on river water governance and a potential framework for GBM basin This section examines the case of GBM based cooperation with the analytical framework of Rittberger and his colleagues' model of three conditions: Problem, Cognitive and Hegemonic conditions (Andreatta and Archibugi 2010), which are empirically used as a prerequisite for the emergence of an international organization. The study advocates for basin based cooperation that can address ecological alteration and resource degradation. Further, it addresses people's desire, that depends on the shared river basin water and it would be able to expand mutual benefits through joint development programs in the basin. Since early 1990s, six countries ${ }^{8}$ within the Mekong River basin have grouped 
together with the assistance of transnational communities (e.g. Asian Development Bank) to facilitate multiple development forums in trans-boundary river cooperation. The following segments unfold the challenges and opportunities of a multilateral cooperation framework in the context of South Asian shared river water with the help of the framework suggested by Rittberger et al. (2006).

The main assumption of the empirical analysis is,

"International Organization emerges when complex interdependencies push states into international cooperation to further common interests ('Problem condition').... not only on the mere fact of the existence of complex interdependencies themselves but also on the realization that these interdependencies lead to problems which can only be overcome through cooperation within international organizations ('cognitive condition').... and when a hegemonic state is willing to bear the costs of the creation of the organization('Hegemonic condition')...we propose that international organizations are created when each of the three conditions deriving from Institutionalist, the idealist and the realist traditions-are met at the same time" (Rittberger et al. 2006, 25).

The paper argues that the conditions Rittberger et al. (2006) have suggested already exist in the case of GBM water governance(see Fig. 2). It is timely to realize the urgency for a series of collaboration among all the countries (China, India, Nepal, Bhutan and Bangladesh) connected by the GBM river basin. The connectivity in between the different conditions of the model offers an integrated resource management and development approach that will improve the existing stagnation and enhance environmental, economical and social development of the basin. The following part elaborates the features of three conditions and how it can play a role towards basin based multilateral cooperation.

\section{Problem condition}

The problem condition emphasizes complex interdependencies among states that lead to further cooperation. This idea is derived from the 'Institutionalist' school that advocates for interest constellation to a specific issue within a certain group of countries before they proceed for further cooperation. Once the actors find out the common interest that expected benefits are higher than expected costs, only then the actors have an incentive for regional cooperation (Rittberger et al. 2006).

The growing demand of water for domestic uses, industrial use in the region is also expected to increase (see Table 2 and Table 3). For example, India's water demand for its domestic, agriculture and industrial sector is expected to be double from 890 million cubic meters in 2006 to 1.4 trillion in 2050 (Wirsing 2007). While the demand of water is mounting in the GBM basin, the supply of water flow is decreasing gradually. The research estimates that India and Bangladesh will have shortfall of water about 70 and $60 \%$ respectively (Condon et al. 2009, 32-33).

Water demand in India requires more diversion of water stream and dam construction on its rivers, including the Ganges. Such activities are likely to be caused more stress on the already tense situation between India and its neighboring states over water resources. A potential impact of loosing livelihood option is internal displacement or cross border forced migration. In such cases of forced population movement, both India and 
Bangladesh are affected. India, as a neighboring country, is one of the easiest destination countries for Bangladeshis. India is already overly populated and such migration has its own socio-economic and security consequences for India. ${ }^{9}$ On the other hand, the construction of Sapta Koshi High Dam ${ }^{10}$ in the Nepalese side of the Indo-Nepal border area, despite facing constant objection from the local people, brought negative externalities for Nepal. The construction of dam affected more than 2600 houses and a population of more than 15,174 (Rotberg and Swain 2007).

Discontinuity in sustainable water supply is another major problem for the riparian countries. The lack of steady water supply in the dry seasons provokes these states to build large water storage dam to conserve monsoon water. Nonetheless, it generates negative consequences for other regional neighbors. In between Bangladesh and India, such tensions will add with the ongoing longstanding conflicting issues-diversion of water by the Farakka and Teesta barrages, Tipaimukh dam and future river linking project. Furthermore, China's recent interest on controlling the Brahmaputra will add more complications to the existing contentious relationship between Bangladesh and India. The possible Chinese diversion of water will reduce the water flow of the Brahmaputra to India and Bangladesh. Therefore, the possibility of environment induced migration will likely increase that exacerbates tension further by destabilizing India. India is also facing internal disputes over the ownership of the basin water. For example, Karnataka has conflicts with Andhra Pradesh with regard to sharing the waters of the Krishna River (Verghese 1997). The underline reason of the conflict is Karnataka's decision to install gates on the Alamati dam in the upper catchment of the river in order to enhance the power generation (Verghese 1997). Moreover, a new plan to divert river water by China will further exacerbate the tension among China, Bangladesh and India.

The GBM basin has a huge potential for hydropower project which is also a contentious issue for the region. All the riparian countries are primarily interested in hydropower for minimizing increased demands of electricity for domestic use, for irrigation, for flood regulation and for energy security. Energy is vital for India's high economic growth. In order to sustain its growth, India may plan and China may keep planning to secure access to new sources of energy. In competing with China, India may also move forward for an expansion of hydropower generation, which will ultimately impose pressure on the already scarce water resources. Although, there is no appropriate data on the energy demand in Bangladesh, Nepal and Bhutan, but these countries are already having huge electricity deficit and are potential to generate hydropower. Nepal and Bhutan, being an upper riparian, have strong interest for the hydropower development since they have huge potentiality for this. Both Nepal and Bhutan lack the capital and technology required for such large projects and also needs a buyer for the surplus hydropower. Although Nepal has some water resource development projects (i.e. waters of the Sarada (1920), the Kosi (1954), and the Gandak (1959) with India, Nepalese always felt discriminated because of their bi-lateral nature of the project (Upreti 1993). Besides with Nepal, Bhutan has also a bi-lateral agreement with India for hydropower development and flood

\footnotetext{
${ }^{9}$ As per 2001 census of India, there are 3,084,826 people in India who came from Bangladesh (source: http://censusindia.gov.in/).

10 The ambitious multi-billion dollar project will combine irrigation facilities, a flood control system, power generation of $3000 \mathrm{MW}$, a 269 -m waterway and construction of an $883 \mathrm{ft}$ high concrete or rock-filled dam.
} 
forecasting network on rivers common to India and Bhutan. By incorporating China as upper riparian and Bangladesh as lower riparian in the process, Nepal and Bhutan may feel comfortable dealing with India in this case.With such realization and the quest for a combined solution, the countries will be able to install interests into action, which is important prior to initiate any regional cooperation (Rittberger et al. 2006).

\section{Cognitive community}

According to Rittberger et al. (2006), the presence of a cognitive community along with the problem situation can enhance cooperation between the concerned countries. The purpose of the cognitive society is to enable states to envisage the value of solving the problem together and will lobby for the specific perception. Being inspired by the Idealist school of thought, Rittberger et al. (2006) justifies the argument with an empirical example of the formation of League of Nations, which was an outcome of conscious community of nations carried specific values and norms of the world peace. Unlike Rittberger and his colleagues, some scholars emphasize such group as 'epistemic community ${ }^{\prime 1}$ or 'international community, ${ }^{12}$ as significant actor for forwarding any progressive regional development agenda. There are also several successful examples of cognitive community that has been formed to work together for sustainable cooperation on regional development. One of such initiatives are taken by the academics from Iraq, Syria, Turkey and United States that has been emerged with an approach to promote sustainable cooperation on regional development called Euphrates-Tigris Initiative for Cooperation (ETIC) (Kibaroglu 2008).

National and trans-national NGOs are also playing effective roles in putting pressure on policy issues upon the governments and at the same time have impacts over the creation on public opinion in social issues. Concerning river water sharing problem, a few civil society organizations ${ }^{13}$ are working in India, Bangladesh and Nepal and are employing greater efforts to address the water problem. Nonetheless, their initiative lack a coordinated approach and they are yet to develop a combined voice. Those initiatives have huge potential for deeper collaboration to show solidarity in the context of river water sharing, dams/s embankments/floods. In Manipur, Action against Tipaimukh (ACTIP) and the Citizens' Concern for DAM and Development were formed and they had established links with Angikar Bangladesh Foundation. Together, these organizations had protested against the construction of Tipaimukh dam in an international conference was

\footnotetext{
${ }^{11}$ Haas provides an articulated meaning of the idea of epistemic communities as 'a network of professionals with recognized expertise and competence in a particular domain, who share a commitment to a common causal model and a common set of political values' (Haas 1992, p. 3 and Haas 1990).

12 It is primarily composed of a network of elite actors (e.g., the global water industry, water research 'think tanks', representatives of the UN system, government representatives, policy experts, and scientific advisors) - pushing a global water agenda reveals little about the socio ecological processes that delineate conflicts and transformations in specific basins (Giordana and Wolf 2003: Sneddon and Fox 2006).

13 Water Nepal Conservation Foundation (established in 1990) is involved in building knowledge, raising awareness and disseminating insights through innovative action carried out in partnership with its field partners (Singh 2008); Jalsrot Vikas Sanstha, (Nepal), works as the regional arm of the Global Water Partnership, and seeks to implement plans and programme on Integrated Regional Water Management (IRWM).; South Asia Network on Dams, Rivers and People (SANDRP) (established in India in 1998), is a network of people working on water issues mostly in India but also in some other parts of SA; South Asia Consortium for Interdisciplinary Water Resources Studies (SACIWATER) is based in India with focus on transforming water resources knowledge system by using an interdisciplinary approach from a pro-poor and human development perspective (Behra 2012); Bangladesh Poribesh Andolan (BAPA) is based in Bangladesh mainly working against India's river linking project along with other national environmental problem; Bangladesh Unnayan Parishad (BUP) is focusing on the Ganges basin and advocating for regional cooperation; And, Bangladesh Unnayan Parishad (BUP) is focusing on the Ganges basin and advocating for regional cooperation.
} 
held in 2005. Moreover, International Centre for Integrated Mountain Development (ICIMOD) and its partners are working to provide credible information and knowledge through its different research programs, such as Regional Flood Information Systems (HKH-HYCOS) and Koshi basin program.

South Asian civil society organizations are identified as key catalysts of change in the field of poverty reduction, women issue, trade and commerce are visible. It creates hope to generate ideas of forming similar civil society movement in the areas of common river water sharing at the regional level. However, it is also important to consider the nature of the states in South Asia that apply despotic power to intervene into the spheres of the civil society as part of the state-led co-optation process. This is also reflected in the structure of the only regional organization, i.e. SAARC, which is state-centric in nature. SAARC has limitations to accommodate non-state bodies as part of the multilateral cooperation framework. In addition to this, NGOs and civil society in South Asia are dependent on external resources (Lewis 2011). Due to such external dependence, it is alleged that the epistemic community and civil society reflect the agenda of the funder. Despite such limitations, civil societies have emerged as a crucial actor and a parallel force to the government in most of the South Asian countries. The political reality is dominant despite the existence of these initiatives that might obstruct in the formation of a perceptional convergence among the actors on regional integrity to call for a multilateral initiative in the river water sharing movement (Tables 1, 2, 3; Figs. 1, 2).

Therefore, there is a high potential that a combined force of civil society and informed experts (i.e. epistemic community) and multilateral bodies (e.g. donors-ADB, WB) can form an effective cognitive community that aims to contribute in collecting and disseminating information among the countries to let the people and government understand the nature of the problem and advocate for workable solutions of the crisis. However, there is not enough perceptional convergence emerged yet among different actors on regional integrity in this region to call it as a combined regional movement. There is an urgent need to develop a cognitive group comprised of government officials, CSOs, NGOs, think-tanks, policy advocacy centers, which will take advocacy role to compel respective countries for searching a common solution for the collective good of the GBM basin. An inclusive cognitive condition does not exclude the role of government experts in such platforms. Moreover, donors should also facilitate government-civil society cooperation through advocating an inclusive cognitive community for river water management. Simultaneously, they will develop consciousness among different stakeholders of the community including the people who will ultimately advocate for a regional movement to promote a common value.

\section{Hegemonic condition}

Rittberger et al. (2006) take the neo-realists conceptualization of hegemonic situation and recognizes it as a third condition for his analytical model. When the hegemonic power is willing to accept the relative gain of other states for the absolute gain of itself, cooperation strategies evolve (see also Kistin 2007; Zeitoun et al. 2008). The paper argues in favor of the leadership role of India as the hegemonic power in the context of establishing the ecological integrity of the GBM river basin. Nonetheless, the role of China is also critical to generate a combined hegemonic condition led by two giant nations of the 
Table 1 Catchment areas of the GBM basins

\begin{tabular}{|c|c|c|c|c|c|c|}
\hline \multirow[t]{2}{*}{ Country } & \multicolumn{2}{|l|}{ Ganga basin } & \multicolumn{2}{|c|}{ Brahmaputra basin } & \multicolumn{2}{|c|}{ Meghna basin } \\
\hline & $\begin{array}{l}\text { Basin area } \\
\left(1000 \mathrm{~km}^{2}\right)\end{array}$ & $\begin{array}{l}\text { Percentage } \\
\text { of total area }\end{array}$ & $\begin{array}{l}\text { Basin area } \\
\left(1000 \mathrm{~km}^{2}\right)\end{array}$ & $\begin{array}{l}\text { Percentage } \\
\text { of total area }\end{array}$ & $\begin{array}{l}\text { Basin area } \\
\left(1000 \mathrm{~km}^{2}\right)\end{array}$ & $\begin{array}{l}\text { Percentage } \\
\text { of total area }\end{array}$ \\
\hline China & 33 & 3 & 293 & 50 & - & - \\
\hline Nepal & 140 & 13 & - & - & - & - \\
\hline Bhutan & - & - & 45 & 8 & - & - \\
\hline India & 861 & 80 & 195 & 34 & 49 & 58 \\
\hline Bangladesh & 46 & 4 & 47 & 8 & 36 & 42 \\
\hline
\end{tabular}

Source: Rangachari and Verghese (2001); Pun (2004)

Table 2 India: projected water shortages

\begin{tabular}{lccc}
\hline & $\mathbf{1 9 9 5}$ & $\mathbf{2 0 2 5}$ & $\mathbf{2 0 5 0}$ \\
\hline Shortage, cubic kilometers & -508.76 & -646.09 & -820.47 \\
Deficit as percentage of total environmental water requirement & 39.9 & 53.3 & 86.0 \\
\hline
\end{tabular}

Source: Upreti (1993); Condon et al. (2009)

Table 3 Bangladesh: projected water shortages

\begin{tabular}{lrrrr}
\hline Year & $\mathbf{1 9 9 0}$ & $\mathbf{2 0 0 0}$ & $\mathbf{2 0 2 5}$ & $\mathbf{2 0 5 0}$ \\
\hline Per-capita water for all of Bangladesh, in cubic meters & 960 & 761 & 504 & 412 \\
Shortage on Falkenmark Index & -40 & -239 & -496 & -588 \\
\hline
\end{tabular}

Source: Condon (2009)

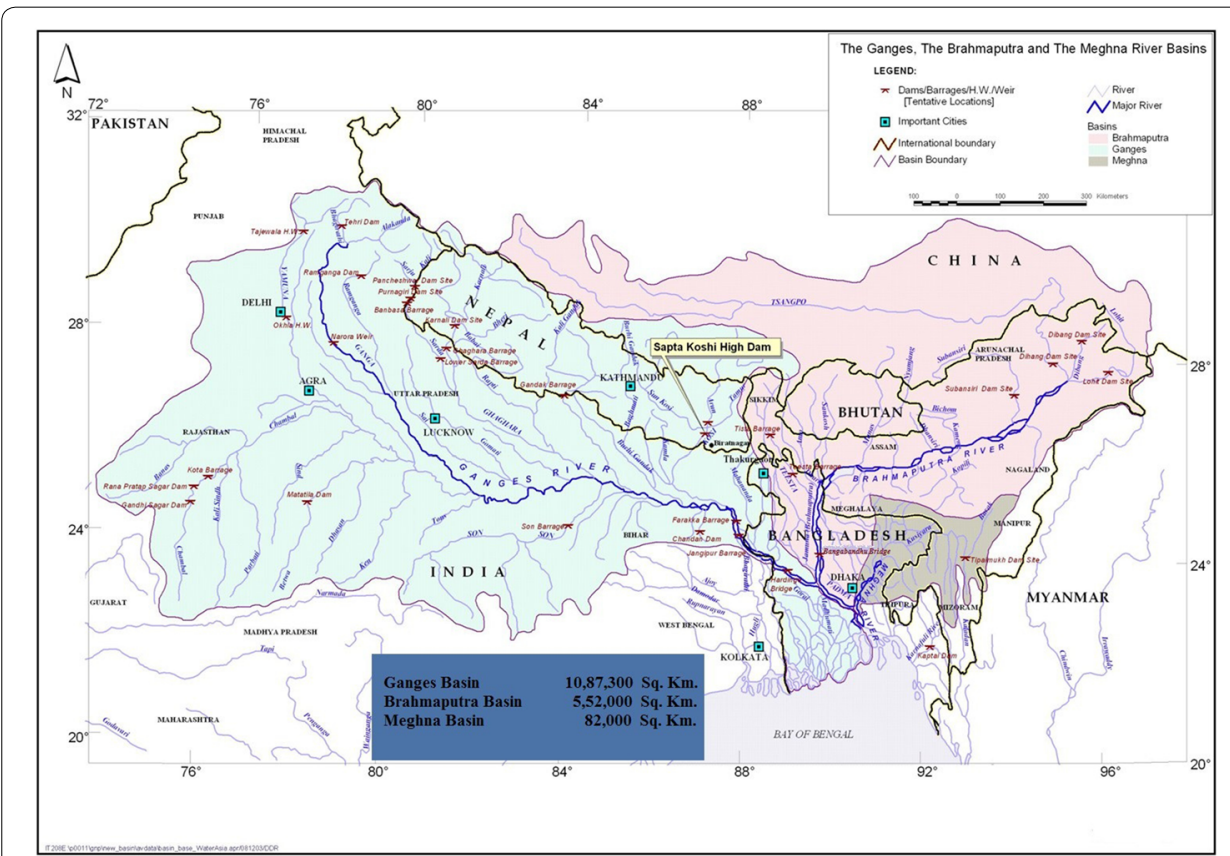

Fig. 1 Water Basin Map in South Asia. The map is collected from: The New Horizon. Towards equitable water allocation in South Asia. https://horizonspeaks.wordpress.com/2009/06/17/towards-equitable-water-usagein-south-asia/ 


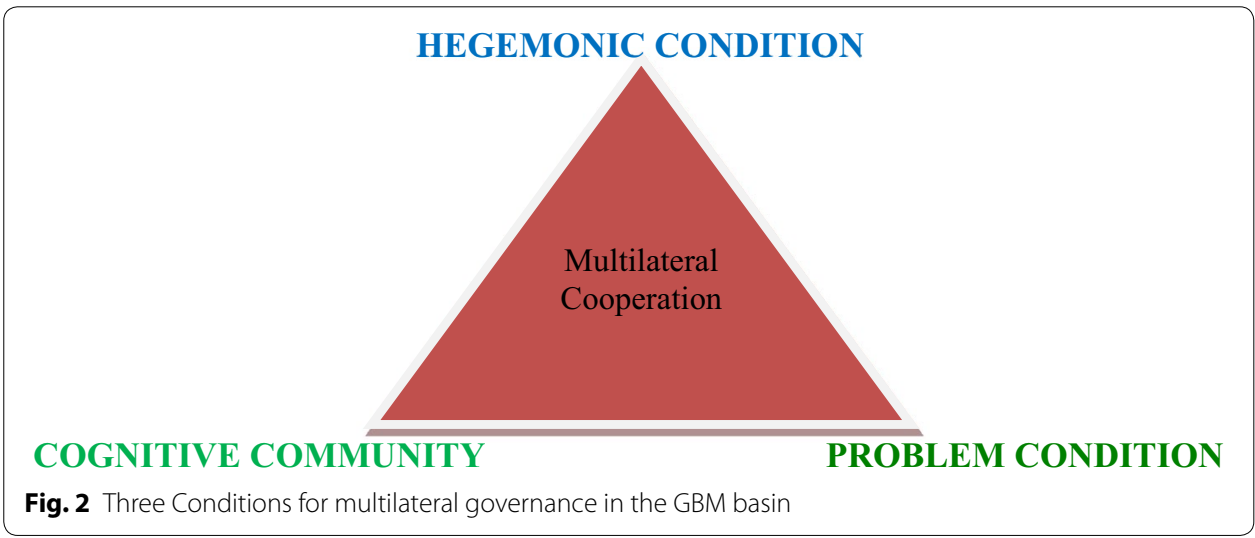

world. The asymmetric inter-state relations between the GBM basin countries are critical in exploring hegemonic conditions for potential cooperation. The discrepancies are already been explained in the prior section of the paper. Such inter-state discrepancies is reflected when a state's voice is projected in any policy matter and also determined by the behavioral patterns of states towards each other.

India is a hegemonic country in terms of size and power, in South Asia (Burki 2011; Dash 2008). The impact of being a hegemon is deep and also visible in the region, when it comes to water sharing negotiations with three other small riparian countries (Bangladesh, Nepal and Bhutan). India remained keen to establish the rights of the lower riparian, but when they dealt with Bangladesh the need of the upper riparian becomes more important (Shahjahan and Harvey 2012). India insisted on separate negotiations with each of the riparian countries to gain benefits from both the countries, although they are sharing the same basin. India's separate approaches with Nepal, Bangladesh and Bhutan in dealing its water shortage explain India's domination over the negotiation process and unwillingness for multilateral cooperation. The research on hegemonic trans-boundary water arrangement shows that more powerful side had greater ability to shape the outcome (Zeitoun, Mirumachi and Warner 2010). However, country like South Africa, being a hegemon in the region, plays a role to play a leadership role with Lesotho and Namibia on the Orange-Senqu River (Turton and Funke 2008) and the development of larger framework of the Southern African Development Community is an example of an integrated approach where power is exercised (Kistin 2007).

In South Asia, Nepal and Bhutan's hydroelectric potentiality can develop their economy further to fulfilling their internal demands and selling the produced energy to India and Bangladesh. The hydroelectricity transfer to India can contribute to India's increasing power demand for its rapid industrialization and population growth, especially in the development of its Northeastern areas. On the contrary, Nepal needs technical and financial supports for which they very much depend on India (Rotberg and Swain 2007). Such mutual beneficial arrangement was successful whereby United States paid Canada for the benefits of flood control and Canada was granted rights to divert water between the Columbia and Kootenai Rivers for hydro-power (Wolf 2007). If India, being the powerful neighbor in the region, initiates regional governance on water sharing issues, India will potentially gain benefits along with the other three countries. More importantly, the trust and faith India can achieve through its leadership role, will help them to overcome 
its longstanding image crisis in the region. India's move from bilateral to multilateral cooperation has many positive implications in the region. Multilateral cooperation can also influence some pending bilateral initiatives positively, for example.

As mentioned earlier, China is an unavoidable force in the region with its critical geopolitical interests. China has already committed to invest approximately $\$ 1.5$ billion to build a dam in Brahmaputra (Nowshin 2015). This has raised some serious concerns in India and Bangladesh. Nonetheless, China has ensured to move forward by utilizing its ideological position of so-called 'soft-path' cooperation and international diplomacy (Wouters and Chen 2013). China has been a major upstream state and a party to more than fifty bilateral and multilateral water sharing agreements. The country consumes the pressure of making a balance between usage and distribution of shared river water to some of the predominant downstream states-Russia and India. At the same time, India has also to bargain its share from the storage of water and hydroelectric projects in Nepal and Bhutan so that they agree to provide a significant downstream benefit (of irrigation, flood control, power as well as navigation and fishing) to India. Under the given circumstances, Both China and India may need to transform its bilateral approach to a multilateral one on the water sharing issues, especially in the case of the Brahmaputra. The whole region-more specifically the lower riparian states-can be benefited in the long run in this broader hegemonic condition in South Asia. For example, Nepal cannot exploit the advantage of its huge water resources potential for hydropower development in the absence of agreements with India and be able to a part of a multilateral framework that would ensure justice to all participant stakeholders.

\section{Concluding remarks}

Countries in the GBM basin region view water as an important resource that fulfils diversified demands of domestic water and energy needs. Crisis with water flows due to environmental and manmade degradations would have serious consequences on the people of the region and influence negative relations among neighbors. Several studies argued for coordinated Ganges basin management approach but the countries sharing the basin could promote social, economic and environmental well being for the whole region (Swain 1993; Swain 2002; Verghese 1999; Rahaman 2008). New kinds of regional agreements are desired among all the GBM riparian countries in order to attain the optimum benefits of water resources for the common good of the whole region. Considering the troubled history of the region, the asymmetric relationship between the countries and level of mistrust, it is quite difficult to address the water shortage of whole region through bilateral arrangement. However, those bi-lateral initiatives offer plenty of common ground and a window of opportunity to foster coordinated and sustainable water resource development and management in the GBM basin region (Rahaman 2009). The study shows the possibility of multilateral governance framework in the region on river water sharing at the GBM basin through the analytical framework of Rittberger et al. (2006). There have been attempts of regional cooperation in a few other environmental issues, however, the success lacks a coordination among the stakeholders on the three crucial conditions-problem, cognitive community, and hegemonic condition. The regional governance system at GBM river basin can be materialized if the problem of water scarcity and preserving of eco-system are considered as a regional interdependent 
problem, thereby, only be resolved multilaterally at the regional levels. The second concern is building of a cognitive community within the four riparian countries. The civil society groups have played influential roles behind bilateral cooperation on the 1996 water sharing agreement between India and Bangladesh and in the 1997 treaty between India and Nepal. In addition, CSOs have actively supported in raising awareness to develop environmental policies in the internal context. Finally, in historical overview of SAARC's limited success, and in the bilateral river water negotiation processes, the common factor is India's hegemonic position. Nonetheless, it is also significant for China to effectively facilitate partnership in South Asia. Only by counterbalancing India's hegemony by China does not bring solution to the water scarcity and existing mistrust over the river water sharing arrangement. Rather, a positive leadership role of India and China by taking the lead, and sharing the cost of the cooperation might be the best alternative solution of the problem. Therefore, a proper utilization of a combined hegemonic attitude as a constructive leadership would bring practical benefits for all the riparian countries. This study constitutes an early attempt of applying this theoretical framework-Rittberger et al's (2006) explanatory model for the development of international organizations-into an area of regional multilateral governance, precisely in river water sharing between GBM basin countries, hence, requires further in-depth investigation with broader scopes and opportunities.

\section{Authors' information}

Marufa Akter is currently pursuing a PhD in Political Science at Bremen International Graduate School of Social Sciences (BIGSS), University of Bremen, Germany. Her research aims to explore the presence of increased numbers of women in the parliament and its influence on women-related policy outcomes in developing democracies. She has been a researcher for the Center for Gender and Social Transformation (CGST), BRAC Institute of Governance and Development, BRAC University in Bangladesh. She also contributes in research and advocacy on issues related to gender and environmental governance, conflict transformation and peace building, and women in politics. She received DAAD Fellowship (2010-2012) to pursue MA degree in Public Policy from The Willy Brandt School of Public Policy, University of Erfurt, Germany.

\section{Acknowledgements}

The author would like to thank the anonymous reviewers and the Special Editor for their detailed comments and suggestions. An earlier version of this paper was read by Dr. Andrea Ribeiro Hoffmann of Willy Brandt School of Public Policy, University of Erfurt. The author is also grateful for her valuable comments on the initial draft of the paper.

\section{Competing interests}

The author declares that he has no competing interests.

Received: 17 December 2015 Accepted: 17 December 2015

Published online: 30 June 2016

\section{References}

Ahmed, Abu Musa Md. Motaher Ahmed and Roy, Kingshuk. 2007. Utilization and conservation ofwater resources in bangladesh. Journal of Developments in Sustainable Agriculture 2(1): 35-44.

Ahmed, Qazi K., and Ahmed, Ahsan U. 2004. Regional cooperation on water and environment in the Ganges Basin: Bangladesh perspective. In The Ganges water diversion: environmental effects and implications, ed. M. Q. Mirza., N. L. Dordrecht. Kluwer Academic Publishers.

Andreatta, Filippo, and Mathias Koenig-Archibugi. 2010. Which synthesis? Strategies of theoretical integration and the neorealist-neoliberal debate. International Political Science Review 31(2): 207-227.

Foundation, Asia. 2015. Strengthening transparency and access to information on transboundary rivers in South Asia. New Delhi: Asia Foundation.

Burki, Shahid J. 2011. South Asia in the New world order: the role of regional cooperation. New York: Routledge.

Chintan, Gopal S. 2011. Trans-boundary river basins in South Asia: options for conflict resolution, international rivers. https://www.internationalrivers.org/files/attached-files/transboundaryriverbasins.pdf. 
Condon, Emma., Hillmann, Patrick., King, Justin., Lang, Katharine., and Patz, Alison. 2009. Resource disputes in South Asia: water scarcity and the potential for interstate conflict. A report prepared for the office of South Asia Analysis, U.S. Central Intelligence Agency, University of Wisconsin-Madison, and La Follette School of Public Affairs.

Dash, Kishore C. 2008. Regionalism in South Asia: negotiating cooperation, institutional structures. New York: Rutledge.

Dhungel, Dwarika N. 2013. Regional cooperation on the Ganga Basin: yet a mirage? Asia Foundation Issue Brief, September. https://asiafoundation.org/resources/pdfs/ORFIssuebrief61DwarikaN.Dhungelformail.pdf.

Dinar, Ariel, Shlomi Dinar, Stephen McCaffery, and Daene Mckinney. 2007. Bridges over water: understanding transboundary water conflict, negotiation and cooperation. London: World Scientific Publishing.

George, Alexander L. and Bennett, Andres. 2004. Case Studies and theory development on the socialsciences. Cambridge Massachusetts: MIT Press.

Giordana, Meredith, and Aaron T. Wolf. 2003. Sharing waters: post rio-international water management. Natural Resources Forum 27(2): 163-171.

Gupta, Avijit. 2008. The monsoon rivers of South Asia: a geomorphological perspective on managing monsoon rivers. In Water first: issues and challenges in South Asia, eds. Kuntala Lahiri-Dutt., Robert J. Wasson. Delhi: sage Publication.

Haas, Peter M. 1992. Introduction: epistemic communities and international policy coordination. International Organization 46(1): 1-35.

Haas, Peter M. 1990. Obtaining international environmental protection through epistemic consessus. Millennium: Journal of International Studies 19 (3): 249.

Iyer, Raghavan. 1990. The Essential Writings of Mahatma Gandhi. Delhi, India: Orford University Press.

Iyer, Ramaswamy R. 1999. Conflict resolution: three river treaties. Economic and Political Weekly 34(24): 1509-1518.

Kibaroglu, Aysegul. 2008. The role of epistemic communities in offering new cooperation frameworks in the EuphratesTigris river system. Journal of International Affairs 61(2): 183-198.

Kistin, Elizabeth J. 2007. Trans-boundary cooperation in SADC: from concept to implementation. Paper prepared for the 8th WaterNet/WARFSA/GWP-SA Symposium Lusaka, Zambia; October 30-November 3,2007

Lewis, David. 2011. Bangladesh: politics, economy and civil society. Cambridge: Cambridge University Press.

Mehdudia, Sujay. Nepal, India and Bangladesh to make most of Ganga water, hydropower. The Hindu, 15 April, 2013. http://www.thehindu.com/news/international/south-asia/nepal-india-bangladesh-to-make-most-of-ganga-waterhydropower/article4617600.ece.

Mirza, Monirul Q., and Q.K. Ahmed. 2005. Climate change and water resources in South Asia. London: Taylor \& Francis.

Nowshin, Nahela. Bangladesh should be worried about China's Brahmaputra dam. The Daily Star, 21 October 2015, http://www.thedailystar.net/op-ed/bangladesh-should-be-worried-about-chinas-brahmaputra-dam-160111.

Observer Research Foundation. 2014. Mekong-Ganga dialogue 2014 towards sustainable development, Delhi: ORF. http://orfonline.org/cms/export/orfonline/modules/issuebrief/attachments/MGD-Report_1426508951886.pdf.

Pun, S. 2004. Overview: CONflICTS OVER The Ganges?. In Disputes over the Ganga, eds. Subba P., Pradhan k. Nepal: Panos Institute South Asia.

Rahaman, Mohammad M. 2009. Principles of tran boundary water resources management and Ganges Treaties: an analysis. International Journal of Water Resources Development 25(1): 159-173.

Rahaman, Mohammad M. 2008. Integrated Ganges basin management: conflicts and hope for regional development. Water Policy 11(2): 168-190.

Rangachari, R. and Verghese, Boobli G. 2001. Making water work to translate poverty into prosperity: the Ganga-Brahmaputra-Barak region. In Ganga-Brahmaputra-Meghna region: a framework for sustainable development, eds. Qazi Kholiquzzaman, A.K. Biswas, R. Rangachari and M.M. Sainju. Bangladesh: The University Press Ltd, Dhaka.

Rasul, Golam. 2015. Water for growth and development in the Ganges, Brahmaputra, and Meghna basins: an economic perspective. International Journal of River Basin Management 13(3): 387-400.

Rotberg, Fiona, and Ashok Swain. 2007. Natural resources security in South Asia. Stockholm: Institute for Security and Development Policy.

Rittberger, Volker, Zangl, Bernhard, and Staisch, Matthias. 2006. International organization: polity, policy and politics. Houndmills[u.a.]: Palgrave Macmillan.

Shahjahan, Mosharefa, and Nick Harvey. 2012. Integrated basin management for the Ganges: challenges and opportunities. International Journal of River Basin Management 10(1): 49-64. doi:10.1080/15715124.2011.644853.

Singh, Richa. 2008. Trans-boundary water politics and conflicts in South Asia: towards 'Water for Peace'. A report of Centre for Democracy and Social Action. New Delhi, India: Centre For Democracy And Social Action (CDSA).

Sneddon, Chris, and Coleen Fox. 2006. Rethinking transboundary waters: a critical hydropolitics of the Mekong basin. Political Geography 25: 181-202.

Swain, Ashok. 1993. Conflicts over Water: The Ganges Water Disputes. Security Dialogue 24 (4).

Swain, Ashok. 2011. Challenging Water sharing in the Nile basin: Changing geo-politics and changing climate. Hydrological Sciences Journal 56 (4).

Swain, Ashok. 2002. Environmental cooperation in South Asia. In Environmental Peacemaking, eds. Conca, Ken and Dabelko, Geoffrey D. United States: Woodrow Wilson International Centre for Scholars.

Turton, Anthony and Funke, Nikki. 2008. Hydro-Hegemony in the context of the Orange River Basin. WaterPolicy 10(2): 51-69

Upreti, Bhuwan C. 1993. Politics of Himalayan river water: An analysis of the river water issues of Nepal, India, and Bangladesh. Jaipur: Nirala Publications.

Upreti, Bhuwan. C. 2006. Nepal: Dilemmas of development and change in far-western hills. Nepal: Indus Pub. Co.

Verghese, Boobli G. 1999. Waters for hope: from vision to reality in Himalaya-Ganga development cooperation. Dhaka: University Press Ltd.

Verghese, Boobli G. 1997. Water conflict in South Asia. Studies in Conflict and Terrorism 20: 185-194.

Wirsing, Robert G. 2007. Hydro-politics in South Asia: the domestic roots of interstate river Rivalry. Asian Affairs 34(1): $3-22$.

Wolf, Aaron T. 2007. Shared waters: conflict and cooperation. The Annual Review of Environment and Resources 32(3): $1-3.29$. 
Wolf, A. T., and Newton, J. T. 2007. Case Study of transboundary dispute resolution: the Ganges River controversy. http:// www.transboundarywaters.orst.edu/research/case_studies/Ganges_New.htm.

Wouters, Patricia, and Chen Huiping. 2013. China's 'Soft-Path' to transboundary water cooperation examined in the light of two UN global water conventions-exploring the 'Chinese Way'. Water Law 22: 229-247.

Yoffe, Shira, Wolf, Aaron T., and Giordano, Mark. 2003. Conflict and cooperation in international freshwater resources: indicators of basin at Risk. Journal of Americans Water Resources Association 1109-1129.

Zeitoun, Mark and Mirumachi, Naho. 2008. Transboundary water interaction I: reconsidering conflict andcooperation. International Environmental Agreements: Politics, Law and Economics 8(4): 297-316.

\section{Submit your manuscript to a SpringerOpen ${ }^{\circ}$} journal and benefit from:

- Convenient online submission

- Rigorous peer review

- Immediate publication on acceptance

- Open access: articles freely available online

- High visibility within the field

- Retaining the copyright to your article

Submit your next manuscript at $\mathbf{s p r i n g e r o p e n . c o m ~}$ 